\title{
Evolution of Bangalore city's water tank system
}

\author{
F. S. Saidoddin ${ }^{1}$, A. Suseelan ${ }^{2}$ \& A. Krishna ${ }^{2}$ \\ ${ }^{1}$ Acharya's NRV School of Architecture, Bangalore, India \\ ${ }^{2}$ Dept. of Architecture, R.V.C.E., Bangalore, India
}

\begin{abstract}
Many of the cities have previously emerged as settlements, along water bodies. The relation between settlements and water is unique and important. This paradigm of water, which is considered a source that sustains life, nurtures occupations and supports religious beliefs is inherent in traditional cities. Presently, there is a shift in paradigm with urbanization and globalization, and the ill-effects of negating water have caused urban ecological imbalance, pollution, unhygienic conditions and floods. Trends of development and increased land demands have caused encroachment of tank beds, sewage disposal into tanks and nalas. The study addresses a historical perspective of the system of tanks or kalyanis that existed in the city of Bangalore for over four centuries, focusing on the Arkavathi and Pinakini River Basins, the Water Network System in Bangalore city, and the Planning principles and land use allocation considering topography. An understanding of the tank system would help the community to conserve this unique asset of the city. The water network as a structuring element, which also renders Bangalore an identity is also highlighted.
\end{abstract}

Keywords: water bodies, settlements, encroachment, land use, topography.

\section{Introduction}

Historical settlements along water developed into port cities, trade centers, administrative capitals, recreational centers, religious/pilgrim towns etc. But in Bangalore, there is no natural perennial source of surface water. Bangalore city is characterized by hills, plains, valleys and undulating terrain, which is typical of the Deccan Plateau. The city depended on a system of tanks that were 
constructed identifying the natural valleys and topography. The construction of tank system was based on the principle of cascading.

The tanks were initially constructed to cater to the agricultural and domestic needs of the settlements. Hence, most of tanks and their connectors (nalas) have institutional land uses abutting them. But, in the present times, the demand for land has engulfed tank beds and the unplanned developments have converted nalas into sewage corridors. The tank system, which was a man-made feature, has acquired diverse roles in the urban landscape, and is an integral part of the cityscape since four centuries.

An understanding of the tank system as a whole and its influence on the city may help to invoke a sense of responsibility and pride in possession of this sensitive layer of the city.

\section{Water and its relation to settlements}

Historically, settlements and civilizations happened along water bodies. These settlements grew into cities which flourished as port-cities along sea coasts, agricultural cities along the fertile plains and deltas of river basins etc. Some settlements have taken advantage of the natural features - topography and climatic conditions of the area, and evolved a system of tanks or lakes, considering the watersheds and catchments; as lake cities or cities of lakes.

Most of the primary occupations in these cities were a response to the nature of the water body present. The coastal cities flourished as trade cities, and have become the major ports and harbors, in the present times; for example - Madras, Bombay, Mangalore and Cochin. The cities which have evolved along the fertile river beds, flourished as agricultural lands and went ahead to become capitals of the provincial rulers; such as - Delhi and Agra along Yamuna, Srirangapatna and Tanjore along Kaveri. Certain other cities became religious or pilgrimage centers; as Mathura, Varanasi, Kumbakonam etc. The lake cities have either evolved on the banks of a single lake, like Nainital, Srinagar etc. or have a system of lakes like Udaipur, Jodhpur, Jalgaon, Bangalore etc.
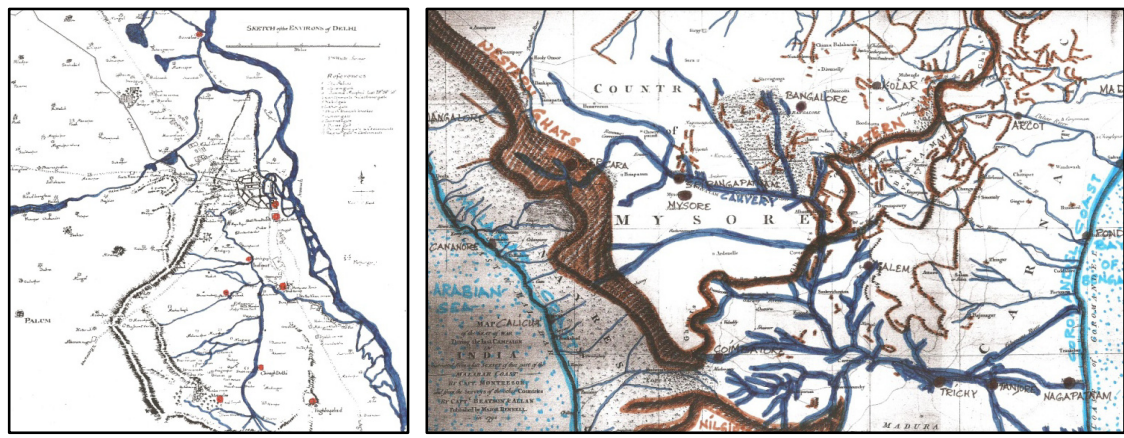

Figure 1: Yamuna and Cauvery river basins in North and South India. 


\section{The context of Bangalore city}

Bangalore is located in the Deccan plateau, in the South Indian peninsula. The Deccan plateau is bound by Vindhyas to the North, Ghats to the East and the West and Nilgiri hills to the South.

At the regional level, Nandi Hills formed the apex of the ridge, from where water would flow in different directions [1]. In Bangalore, the main ridge-line runs North-west and South-east direction dividing the city into two river basins Arkavathi river basin and Pinakini river basin. The Arkavathi river basin is to the west with steep slope and undulating terrain. But the Pinakini river basin is to the east with gentle slopes and valleys.

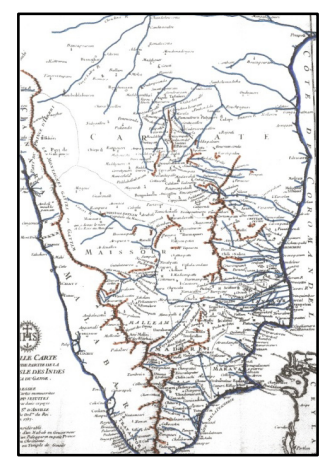

Figure 2:
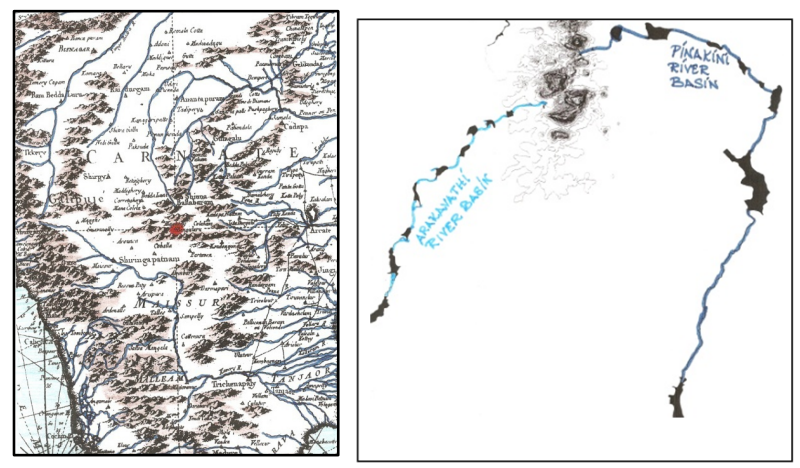

Location of Bangalore in the Deccan plateau.
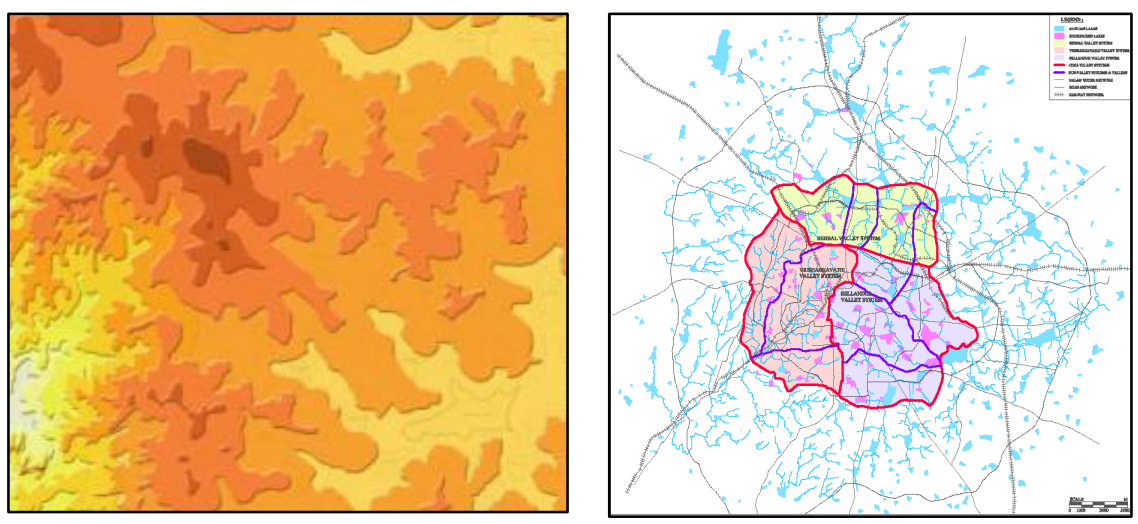

Figure 3: $\quad$ Contour map and valley systems of Bangalore.

The contour map of the city shows a radial pattern, from the High-Grounds at the apex, occupying the highest position [2]. The water is drained off into the low-lying plains - Vrishabhavathi (south-west), Hebbal (north east) and Bellandur (south-east). 


\section{The tank system of Bangalore city}

Initially, there existed a system of water tanks, constructed identifying the natural valley systems in the region. These tanks were fed by the valleys (nalas), which carried surface run-off during rains. The tanks stored the run-off water during monsoons, to be used during lean period. The tank system worked on the principle of cascading. The tanks formed chains, situated in the same catchment area, which depended on surplus water from the tanks at higher elevation and the run-off from their catchment [1].

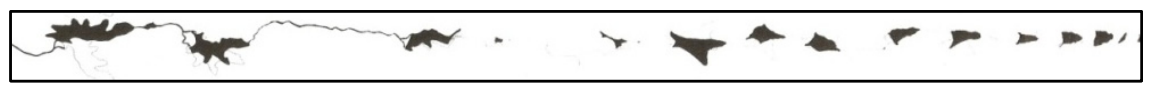

Figure 4: The cascading system of tanks.

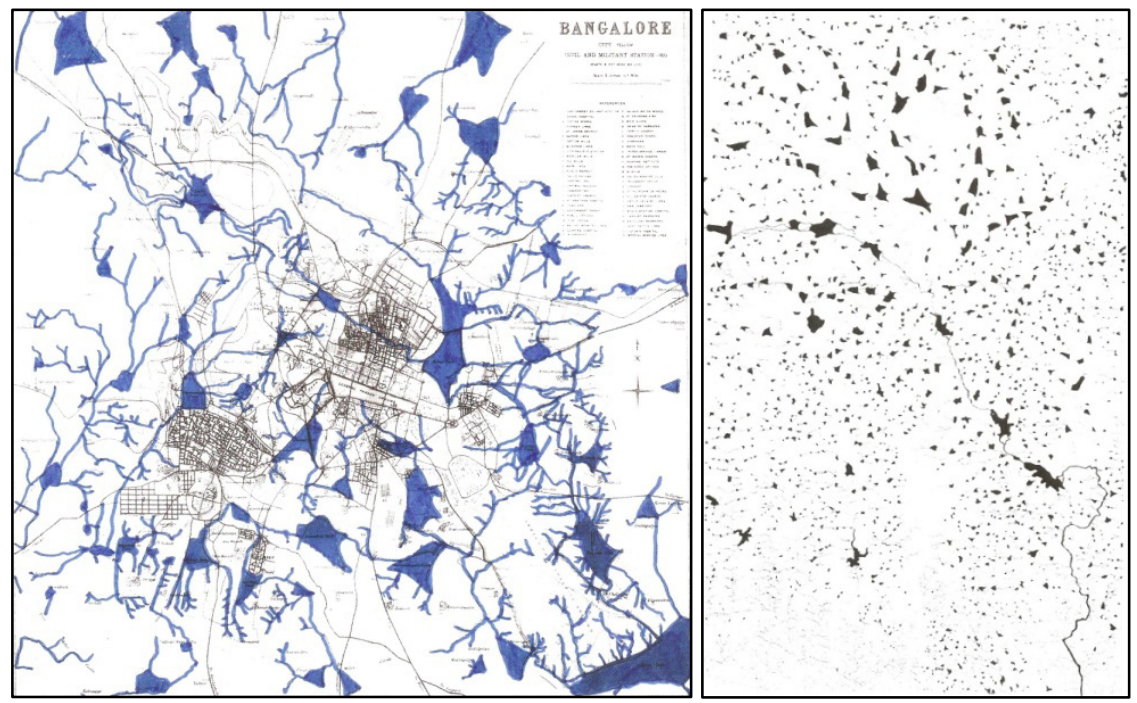

Figure 5: The Interlinking system of tanks at the city level and Regional level (The Region of Thousand Tanks).

The tanks within the city formed a part of the larger region, referred to as "The Region of Thousand Tanks". Every settlement had a tank for the water requirements of its inhabitants. The tanks catered to the agricultural and domestic needs. The water collection systems were located at lower plains and the settlements occupied higher lands.

\section{The evolution of the tanks system}

Chronologically, the evolution of tank system in the city of Bangalore can be classified as: 


\subsection{The pre-colonial period}

After 1537, Kempambuddhi tank was built in Basavanagudi area, Dharmambuddhi tank in Majestic area, Ulsoor tank in Shivajinagar area, Sampangi tank in Corporation area and Siddikatte tank near City Market area, by Kempegowda-I and Kempegowda-II, for agricultural and domestic needs of the settlements along these tanks. In 1759, Haider Ali and Tipu Sultan expanded an existing mango-orchard into Lal-Bagh, which comprised of a garden and a lake. During this period, the settlements happened along the ridges and the series of tanks were built in accordance with the natural valley systems [3].

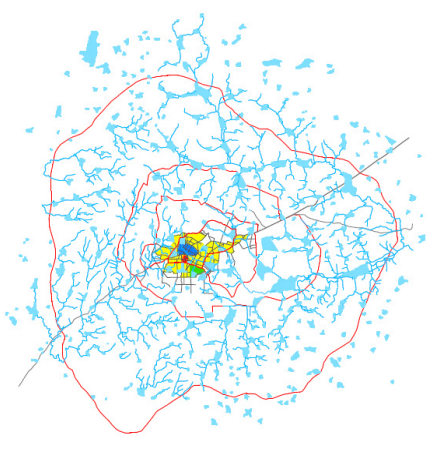

Figure 6: Growth of the city - phase I.

\subsection{The colonial period}

In 1809 , the Ulsoor tank and its adjacent area were developed to cater to the cantonment settlement, which was established close to the lake precinct. The large area made a buffer zone between the cantonment and the old city. In 1831, the British capital was shifted from Mysore to Bangalore, emphasizing on Bangalore's image of a "Garden City", with salubrious climate. The establishment of the cantonment, its residential quarters and a commercial center, triggered the city's growth east-ward, in the Pinakini river basin. Cubbon Park,

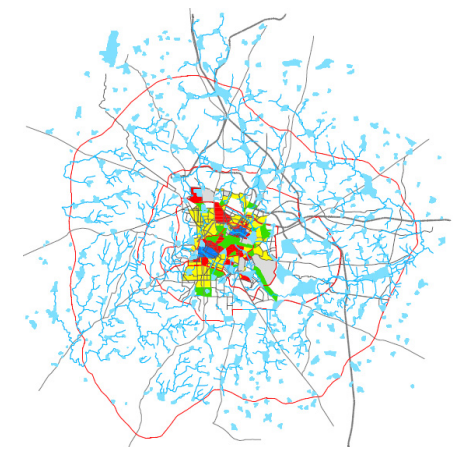

Figure 7: Growth of the city - phase II. 
Golf Course and Race Course were built in the high grounds region, which constituted the apex of the ridge, in the city. In 1870's, when Bangalore had a severe scarcity of water, 'Karanji System' of supplying water existed in the fort area.

In this system, a "water-bearer" with tanned skin-container supplied lifesaving water, drawn from kalyanis/ tanks. Hence by 1873, a string of three tanks in a huge area known as 'The Millers Tanks' were erected, as the primary source of piped water to the Cantonment area, along with the Ulsoor tank. The influx of people from various regions accelerated the ever-increasing demand for water and the authorities had to look for new source of water supply. Sankey Tank was constructed at Sadashivanagar in 1882, by Col. Richard Sankey, to supply water to the Civil and Military Station in Bangalore. This was connected with Millers Tank and onwards to Dharmambuddhi Tank through contour channels. When Sankey Tank overflowed, water would flow into Millers Tank and then to Dharmambuddhi. This linking of lakes continued to save the city, during heavy downpour. This system of tanks was known as 'Inter-linking system of tanks'.

In 1896, Hesaraghatta reservoir was constructed across Arkavathi River, $20 \mathrm{kms}$ to the north-west of Bangalore, to supply piped water through meters. The transportation network, with roads along lakes, isolated the tanks as traffic islands. The supply of piped water from reservoir led to the neglect of water bodies, in the city. The sewer lines and storm water drains ran along the natural valleys, which resulted in mixing of the two. Thereby, turning the seasonal storm water drains into perennial sewage channels, with sewers directly opening into them.

\subsection{The pre-independence period}

In 1925, Hessarghatta reservoir dried up completely. Efforts were made to restore water supply to the city form Yelemallappa Chetty Tank, Byatha and Kakol tanks. Hence, Tippegondanahalli dam was constructed across the Arkavathi River in 1933, to bring treated water into the city.

To cater to the growing city and its increasing density, recreational spaces were laid on dry tank-beds - a part of Ulsoor and Domlur tanks, Dharmambuddi, Shule and Sampangi tanks. Koramangala tank was breached to be used as a vegetable garden.

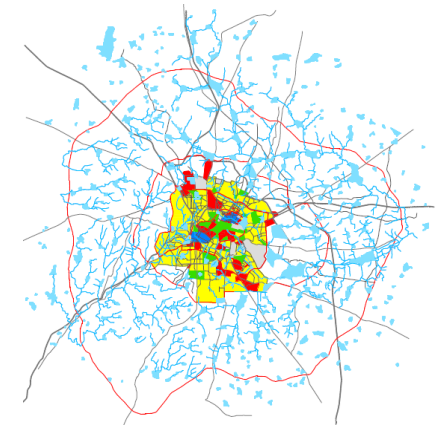

Figure 8: $\quad$ Growth of the city - phase III. 


\subsection{The Post-independence period}

In 1950s, the growth of Bangalore city was triggered by the establishment of five satellite towns, as industrial townships - H. A. L., H. M. T., I. T. I., Banaswadi and north of Tannery Road. With industrialization, there was a sudden influx of people from different parts of the country, which led to the scarcity of water again. Hence, Bangalore Water Supply Sewerage Board (BWSSB) was set up in 1974. The BWSSB depended on Cauvery, as a source to tap water for the city.

The Master Plan of 1965, proposed to conserve Sankey tank, Hebbal tank, Nagawara tank, Challaghatta tank, Bellandur tank, Madiwala tank, Sarakki tank and Kempambuddhi tank.

Industrialization led to alternate employments and reduced the dependency on tanks, unlike agriculture. It encouraged migration of people into the city, increasing the population and the demand for land. This led to the negligence and encroachment of tanks.

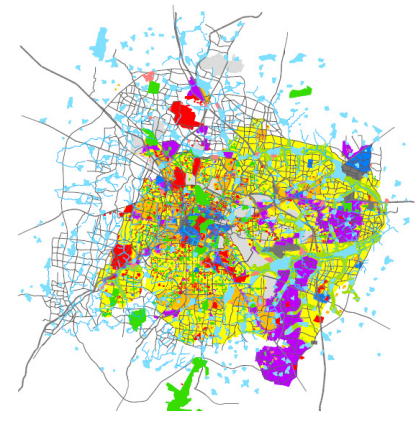

Figure 9: $\quad$ Growth of the city - phase IV.

\subsection{The current period}

Initially the land uses along valleys and ridges, sought to protect the watershed zones, with the location of institutions, parks, gardens etc along their edges. But later the tank beds were encroached upon to house transportation terminals, residential layouts, educational institutes, sports stadiums and complexes,

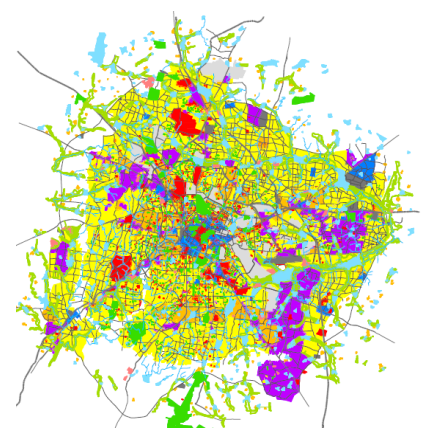

Figure 10: Growth of the city - phase V. 
Table 1: $\quad$ The encroachment of tanks.

\begin{tabular}{|c|c|c|l|}
\hline \multicolumn{4}{|c|}{ Encroachment of Tanks } \\
No. & Tank Name & Location & \multicolumn{1}{|c|}{ Present Land-Use } \\
\hline 1 & $\begin{array}{c}\text { Dharmambuddhi } \\
\text { Tank }\end{array}$ & Gandhinagar & Kempegowda Bus Terminal \\
\hline 2 & Karanji Tank & $\begin{array}{c}\text { Chamarajpet, } \\
\text { Gandhi Bazaar, } \\
\text { Basavanagudi }\end{array}$ & $\begin{array}{l}\text { National High School, } \\
\text { Residential Layouts }\end{array}$ \\
\hline 3 & Sampangi Tank & Corporation & $\begin{array}{l}\text { Kanteerava Stadium, parks and } \\
\text { institutions }\end{array}$ \\
\hline 4 & Siddikatte Tank & Kalasipalyam & Krishna Rajendra Market \\
\hline 5 & Miller's Tank & $\begin{array}{c}\text { Vasantnagar, } \\
\text { Shivajinagar }\end{array}$ & $\begin{array}{l}\text { Ambedkar Bhavan, IT and } \\
\text { office Buildings, Jain Hospital, } \\
\text { Marriage Halls, Other Public } \\
\text { Organisations }\end{array}$ \\
\hline 6 & Mathikere Tank & Yeshwantpur & Regional Park (J. P. Park) \\
\hline 7 & Challaghatta Tank & Koramangala & K. G. A. Golf Course \\
\hline 8 & Koramangala & Koramangala & N. D. R. I., Sports Complex \\
\hline 9 & Shule Tank & Ashoknagar & $\begin{array}{l}\text { Commercial Establishment, } \\
\text { Football and Hockey Stadium }\end{array}$ \\
\hline 10 & Tumkur Tank & Yeshwantpur & Mysore Lamps Factory \\
\hline 11 & Gangashetty Tank & Minerva & Minerva Mills, Open Ground \\
\hline 12 & Sunkal Tank & Shantinagar & $\begin{array}{l}\text { Shantinagar Bus Stand, Slums, } \\
\text { K. S. R. T. C. Regional } \\
\text { Workshop }\end{array}$ \\
\hline
\end{tabular}

hospitals, public offices, industries, community halls, markets, regional parks, textile mills, slum rehabilitation, exhibition and demonstration grounds etc.

But now, there have been measures taken by the governing authorities to conserve this sensitive layer, which structures the city.

\section{The importance of tank system}

Ecologically, these tanks have become wetland ecosystems, which sustain and attract many species of birds, insects, fishes etc. Disturbing and manipulating of the water network may result in the ecological imbalance in the urban areas.

Hydrologically, the tank systems check flash floods, due to heavy rains in low lying areas. They reduce soil erosion, by trapping sediments and by regulating run-off. Breaching of tanks at higher elevation has resulted in flash-floods in low-lying areas, like Madiwala, Koramangala, Wilson Garden etc.

Climatologically, they influence the micro-climate of their surroundings. They reduce surface radiation, regulate humidity, maintain soil moisture, reduce 
surface temperature and cool the atmosphere. The encroachment of tanks has resulted in reduction of water-spread area, thereby changing climatic conditions and increasing temperatures.

Recreationally, the tanks and its adjacent areas are used as parks, gardens, water-sports, boating, bird-watching clubs etc.

Religiously, the tanks are embanked by institutions. There is presence of shrines along the edges of tanks. Tanks are used for immersion during festivals etc.

Socio-economically, the tanks can be used to generate employment, through various activities, like cultivation, fisheries, recreation, hawking along lake promenades, etc, which in turn generates economy.

Educationally, the tanks can be used for the biological study of ecosystems and their flora and fauna, for water supply, sewage treatment and related activities, botanical and horticultural activities in adjacent parks and gardens etc.

Infra-structurally, tanks can be used as alternate sources of water, even during the present times. The tanks can be recharge points for the under-ground watertable. The water treatment plants and sewage effluent treatment plants can be setup along tanks to re-use the water for landscaping etc.

Structurally, the tanks and their connectors, essentially form the first layer, that structures the city as water network. This layer is super-imposed by other layers, like road network, rail network, commercial network, industrial network, open space/ landscape network etc.

\section{The present trends in development}

With the change in lifestyles and occupations after industrialization, the relationship between settlements and water has changed. With alternate sources of water in the city, the dependency on these tanks has declined. With globalization and urbanization, the present trends of development have resulted in negation of this sensitive water network structuring the city. The growing cities have encroached upon tank-beds and nalas for provision of housing, infrastructure, services etc. But the existence of these tanks, forming the softscape of the city, from past four centuries, has a deep impact on the environment and climatic conditions of the city. Now, the tank system is an inseparable part of the urban landscape.

\section{Conclusions}

The lack of understanding of the water network is the main reason for its present state. The network lost its importance with changes in life style and trends in development. But now, the importance of this network has been understood, where the efforts of restoration and de-silting of tanks are seen. But, for the proper working of the system, a holistic approach should be adopted in trying to understand, analyze its working and initiate its revival.

Hence, there is a dependency of the city on this network. However, if this is emphasized with the various roles it performs along with the change in the 
attitude of development, then the sense of responsibility, pride and ownership will be induced among the citizens, towards uniqueness of Bangalore city.

\section{References}

[1] Mathur, Anuradha, and Da Cunha, Dilip, Deccan Traverses, Rupa \& Co., Delhi, 2004.

[2] Mahalakshmi, K., "Trends in Urban Development around Water Tanks in Bangalore", Paper Presented in Symposium - Lake 2002, I.I.Sc., Bangalore, 2002.

[3] Rice, Lewis, Mysore: A Gazetteer Compiled For Government, Vol. II, Archibald Constable \& Company, Westminster, 1897. 